\title{
Didin Hafidhuddin's Leadership Style in Managing National Zakat Agency (Badan Amil Zakat Nasional)
}

\author{
Muthoifin \\ $\{\underline{\text { mut122@ums.ac.id }\}}$ \\ Universitas Muhammadiyah Surakarta
}

\begin{abstract}
The purpose of this research is to uncover the style or type of leadership of Didin Hafidhuddin in managing and leading BAZNAS (National Zakat Agency) during this time. Where the figure of a leader will certainly affect the results and objectives of a body or institution that he leads. In addition, one's style and type of leadership will certainly influence the achievement and progress factors as well as the decline of an organization. The methodology used in this study is qualitative and patterned library studies. While the data was collected through the search of written relics, either in the form of books, journals, or proceedings relevant to the theme of research. The approach used is phenomenology, historical approach, biography, and normative. Data Analysis Techniques are processed in the form of content analysis, namely: analyzing data following the content of its contents. also, a comparative technique is a method by comparing two or three events by looking at the cause and reason. The result of the study that Didin Hafidhuddin leadership style is the type that often gives direction and gives a lot of support, able to provide the role of model subordinates, directives leadership supportive leadership participative leadership. achievement leadership, and Islamist style (sidiq, amanah, tabligh, and fathonah).
\end{abstract}

Keywords: Leadership, zakat, managing, direction, Islamic style, Didin Hafidhuddin

\section{Introduction}

Discussing the issue of leadership and zakat in Indonesia certainly can not be abandoned discussion of a figure named Didin Hafidhuddin, an expert who is involved and concentrates his expertise in the field of da'wah and Islam, especially in the issue of ZIS (zakat, infak, and alms) [1]. This is due to various strategic concepts about Baznas (National Zakat Agency) and Laznas (National Zakat Institute) in Indonesia almost all aspects always refer to his thinking [2].

A figure was worthy to be studied model and leadership style has been awarded the most prestigious award by the President of the Republic of Indonesia Joko Widodo, namely Main Service Star for his outstanding services in a particular field. Surely this award has a deep meaning for him who has the type and style of leadership and Baznas in general that he has led so far [3]]

The offense between Didin Hafidhuddin and zakat is from the accumulation of his experience that occurred long before he took office Director Baznas, namely he was indirectly always involved in problems related to the social society around him, even his concern for national and world-scale social problems. One of them is about the issue of generality based on zakat, infak, and shadaqah (LAS). This can be traced from his work about zakat in the rubric of q\&a about zakat infak shadaqah in Republika newspaper [4]. 
Seeing the importance of style and leadership, where a body or organization anywhere and anytime can certainly be seen from the type and style of a person in leading his institution, both public institutions, and Islamic institutions. The fundamental problem of this research is to reveal the leadership style of Didin Hafidhuddin in managing the National Zakat Agency, moreover, the activities of zakat and the like are considered as an activity that is very enlightening and brings a lot of universal good both in the world and in the hereafter [5].

The purpose of this research, also to uncover and study it in the view of Islamic leadership, where the main purpose of the creation of man on earth in the Islamic perspective is in addition to worshiping Allah Almighty, he must also be the leader (caliph) on earth. tools to carry out the task human need the right knowledge and concept in navigating it [6].

Once the importance of this research was carried out, to reveal Didin Hafidhuddin's leadership style, of course, the aim was that this model could be imitated by current and future young generations in Indonesia in managing and leading their respective institutions, for this reason, this research is very feasible to be continued and developed for mutual progress [7].

\section{Research methods}

The model used in this study is qualitative and includes library studies. Data collection through the search of written relics, both in the form of books and scientific journals relevant to the issue discussed [7] . The approach used in this study is the historical approach in other words the method of historical research is an instrument to reconstruct historical events (history as past actuality) into history as written. Another approach in this study is the biographical approach. That is by talking about, expounding on the thoughts or views of figures, religionists, politicians, or historians. In addition, the authors also use normative approaches and phenomenology [8].

Data Analysis Techniques are processed in the form of content analysis, namely: analyzing data following the content of its contents. also, a comparative technique is a method by comparing two or three events by looking at the cause and reason [9]. This technique is used as a comparison effort to obtain comprehensive maximum results. while the measures used include: a) topic selection, b) resource collection, c) verification (historical criticism, validity of sources), d) interpretation (analysis and synthesis), e) historiography or writing, and f) inference [10].

Primary data sources use works or books or journals written by Didin Hafidhuddin. While the secondary data from various collections of scientific works that discuss his thoughts on zakat and leadership styles correlate with activities in the world of zakat and Islam [11].

\section{Results and discussion}

\subsection{Biography of Didin Hafidhuddin}

Didin Hafidhuddin who was born in Bogor on October 21, 1951, was raised in a religious family, both his parents are community leaders who have boarding schools in his area, the boarding school environment indirectly formed a strong mindset and personality for his Islamic understanding [12].

Didin Hafiduddin completed his education at The Islamic Primary School in 1963, Junior High School in 1966. High School in 1969. In 1980 he completed his Bachelor's degree at IAIN (Institut Agama Islam Negeri) Syarif Hidayatullah now UIN (Universitas Islam Neger) Jakarta in sharia. After graduating from IAIN, he continued his master's degree in Institut Pertanian Bogor (Bogor Agricultural Institute/IPB) by majoring in National Development Counseling and finished in 1987 by obtaining an award as the best Master's graduate in IPB [13] .

Didin then went on to the Islamic University of Medina, taking a Diploma in Arabic, and graduating in 1994. After returning to Indonesia, Didin continued his master's school at UIN 
Syarif Hidayatullah and graduated in 2001 [14] (Sudarno Shobron, Mutohharun Jinan, MA Fattah Santoso, Muthoifin 2020) The dissertation in obtaining his Doctorate was then recorded with the title, "Zakat in the Modern Economy" [15].

From 1989 to 2021 he was still studying Tafsir at the Faculty of Islamic Religion, Universitas Ibn Khaldun (UIKA) Bogor, and the Faculty of Islamic Studies, Djuanda University Bogor. He served as Rector of UIKA (1987-1991), and currently serves as Postgraduate Director of Ibnu Khaldun University [16].

Also believed as the leader of the boarding school Ulil Albab YPIKA Bogor (1987 until now), as well as Secretary of the Board of Leaders of the Indonesian Boarding School Cooperation Agency (BKSPPI), also as a member of the Central Leadership of the Indonesian Islamic Da'wah Council (DDII) [ (Shobron and Rahman 2019) Since 1996 until now trusted as a member of the Sharia Council Wallet Du'afa Republika, as well as nurturing public consultation Zakat, Infak, Alms (ZIS) in the daily Republika also as chairman of the Sharia Council BPRS Amanah 'Ummah Leuwiliang Bogor and as a member of the Board of Trustees BAZIZ DKI-Jakarta [17].

Didin Hafidhuddin has also translated several books from Arabic to Bahasa Indonesia, such as Fiqh Zakat (Yusuf Qardhawi), Minhaj al-Muslim (Muhammad Abu Bakar al-Jazairi), Israiliyyat fit a-Tafsir Wa al-Hadith (Muhammad Husein Az-Zahabi), Daur al-Qiami wa alAkhlak al-Iqthishadi al-Islam (Dr. Yusuf Qardhawi), and also one of the authors of the book Islamic Intellectual Heritage of Indonesia and the book Sick Strengthen faith[18]. Didin Hafidhuddin's religious insights are strongly influenced by the journey of studying in various pesantren, a very high concern for students and students, to lead him to become a leader [19].

In addition to leading pesantren. Didin often held and led regular studies in various taklim assemblies, among which he led the reading of tafsir Jalalain, Shahih Bukhari, Muhtar alAhadits, and Kifayah al-Akhyar. Tafsir al-Hijiri is a monumental work of Didin that makes him one of the mufassir in Indonesia [20].

His research related to zakat: Conceptualistic Strategy of Collection and Utilization of Zakat, Infak, and Shodaqoh; sources of zakat in the modern economy; a case study of Wallet Dua'fa Republika, Bait al-Mal al Muamalah, and BAZIZ DKI Jakarta. While career and work experience concerning the field of zakat and leadership include: Rector of Ibnu Kholadun University Bogor; Dean of the Faculty of Islamic Religion UIKA Bogor; Chairman of STIE Syariah Economic and Banking Institute (SEBI); Chairman of Sharia Bank Bukopin Board, Bank Syariah IFI, Bank Syariah Amanah Ummah Bogor; Chairman of ICMI advisory board Bogor region; Member of MUI National Sharia Board; Chairman of the Advisory Board of the National Zakat Board (BAZ-NAS); Chairman of the Sharia Council wallet Dua'afa Republika[21].

\subsection{Leadership style}

The pattern and style of leadership are inseparable from one's activities with the theory that exists in the science of leadership [22]. This is where one's leadership style will look. Here are some theoretical frameworks on leadership, style, and type. where in the world of leadership there are several types, and in each type, there are several different styles of leadership[23].

As revealed in Bahruddin's Ending research that there are several styles in leadership activities, among them: a leadership style that often gives direction and gives a lot of support, a leadership style that gives a lot of direction but little support, there is a leadership style that gives little direction but gives a lot of support, and a style that gives little direction and guidance [24]. 
Table 1. Leadership style according to Ending Bahruddin

\begin{tabular}{lcc}
\hline Leadership Style & $\begin{array}{l}\text { Giving } \\
\text { Directions }\end{array}$ & $\begin{array}{c}\text { Providing } \\
\text { Support }\end{array}$ \\
$\begin{array}{l}\text { often give directions and give a lot of } \\
\text { support }\end{array}$ & $\mathrm{V}$ & $\mathrm{V}$ \\
$\begin{array}{l}\text { gave a lot of direction but little support } \\
\text { gave a little direction but gave a lot of } \\
\begin{array}{l}\text { support } \\
\text { give a little direction and sit down }\end{array}\end{array} \mathrm{V}$ & $\mathrm{X}$ \\
\hline
\end{tabular}

Description: V = Many. X = Little

Another type of leadership according to Robert J. House (in Nuha, Sudarno Shobron) [25], in ending Badruddin research, there are four types of leadership [26]: 1). Directive Leadership. 2). Supportive Leadership. 3). Participatory Leadership. 4). Achievement Leadership.

Table. 2 Leadership style according to Robert J. House

\begin{tabular}{lll}
\hline Leadership Style & Leader Type & information \\
Directive Leadership & Leadership Directive & These four style \\
Supportive Leadership & Supportive Leadership & models fall within the \\
Participative & Participatory Leadership & ideal criteria for a \\
Leadership. & leader. \\
Achievement & Achievement-Oriented & \\
Leadership & Leadership & \\
\hline
\end{tabular}

In contrast to the above style and type, Ki Hadjar Dewantara formulated the leadership style is as stated in the concept of leadership tilogy that reads Ing ngarso sung tulodo, Ing madya mangun karso, Tut wuri handayani is derived from the fruit of his thinking [27].

Table. 3 Leadership style perspective of Ki Hadjar Dewantara

\begin{tabular}{ll}
\hline Leader Type & \multicolumn{1}{c}{ Leadership Perspective } \\
Ing Ngarso & a leader must be able to provide suri tauladan for his subordinates \\
Sung Tulodo & or men. \\
Ing Madyo a leader amid his busyness should also be able to awaken or \\
$\begin{array}{l}\text { Mangun } \\
\text { Karso }\end{array}$ & encourage the work of his subordinate members \\
Tut Wuri & A leader follows behind while exerting a good and evocative \\
Handayani & influence.
\end{tabular}

While in Islamic thought, a good leader is a leader who is like the ideal teacher of the Prophet Muhammad, who is blessed with four main foundations, namely: Sidiq, Amanah, Tablig, and Fathonah. Sidiq means honest in words and deeds, trust means trustworthy in maintaining responsibility, Tablig means conveying all kinds of good to his people and fathonah means smart in managing society [28]. 
Table. 4 Leadership style of the Islamic perspective (Shobron and Anshori) [29]

\begin{tabular}{|c|c|}
\hline $\begin{array}{l}\text { Islamic } \\
\text { leadership }\end{array}$ & Intent and Relevance \\
\hline $\begin{array}{l}\text { Siddiq } \\
\text { (Honest) }\end{array}$ & leaders and teachers in front must be honest in their attitudes and \\
\hline $\begin{array}{l}\text { Amanah } \\
\text { (Trusted) }\end{array}$ & $\begin{array}{l}\text { leaders and teachers in front and the middle must be trustworthy } \\
\text { and fair in solving and providing solutions to the problems of the } \\
\text { material. }\end{array}$ \\
\hline $\begin{array}{l}\text { Tabligh } \\
\text { (Conveying) }\end{array}$ & $\begin{array}{l}\text { leaders and teachers in front and center should be able to convey } \\
\text { ideas in communication and diplomatic }\end{array}$ \\
\hline $\begin{array}{l}\text { Fathonah } \\
\text { (intelligent) }\end{array}$ & $\begin{array}{l}\text { leaders and teachers must have a history and a background that } \\
\text { is above the average of the community so that they have the } \\
\text { confidence to encourage the progress of the community and its } \\
\text { students. }\end{array}$ \\
\hline
\end{tabular}

From the various styles and types stated above, it turns out that Didin Hafidhuddin's leadership style in managing Baznas, it can be read that he is a figure who can give direction and give a lot of support, a figure who can provide suri tauladan for his men, a figure who is in the midst of his busy life can awaken or encourage the work of his subordinates, a figure who if in the back can give a good influence and encourage his protégé can be seen from his leadership to be the chairman of Baznas in Indonesia and received appreciation and appreciation from President Joko Widodo, an Islamist figure (sidiq, amanah, tabligh, and fathonah) seen from his leadership in leading the study of interpretation in various Islamic activities [30]. So it is clear that his involvement in leading Baznas is an accumulation of various previous experiences, namely leading pesantren and institutions both social, campus, and government institutions.

Therefore, all research data about Didin Hafidhudin's leadership style that has been discussed in the discussion, and according to the rules of data collection techniques, and analysis is carried out, whether each data that appears shows a trend of results that are following the type of leadership, according to the researcher's analysis, it is following the type of leadership. types of styles that exist in Islamic leadership, and the concept of leadership initiated by Ki Hadjar Dewanatara, namely Ing Ngarsho Sung Thuladha [18][30].

\section{Conclusion}

The conclusion of this research was found that Didin Hafidhuddin's leadership style in managing Baznas, as in managing other institutions both pesantren, universities, public institutions, and government institutions are with a style and type that often gives direction and gives a lot of support, leaders who can provide suri tauladan for subordinates (ing ngarso sung thulodo), amid his busyness should also be able to awaken or encourage the work of subordinate members (Ing madyo mangun karso), the leader follows behind while giving a good and uplifting influence (tut wuri handayani), directives leadership supportive leadership participative leadership. achievement leadership, and Islamist style (sidiq, amanah, tabligh, and fathonah). Once the importance of this research was carried out, to reveal Didin Hafidhuddin's leadership style, of course, the aim was that this model could be imitated by current and future young generations in Indonesia in managing and leading their respective institutions, for this reason, this research is very feasible to be continued and developed for mutual progress. 


\section{References}

[1] Naufal A, Hafidhuddin D, Beik IS. STRATEGI PENGELOLAAN ZAKAT DALAM MENANGGULANGI PEMURTADAN DI KABUPATEN GUNUNGKIDUL YOGYAKARTA. Kasaba: Jurnal Ekonomi Islam. 2019 Sep 24;11(2):203-16.

[2] Muklisin M. Strategi Pengelolaan Zakat dalam Upaya Pengembangkan USAha Produktif (Studi Kasus pada Baznas Kabupaten Bungo). JURIS (Jurnal Ilmiah Syariah). 2018 Dec 31;17(2):205-14.

[3] Hafidhuddin D, Beik IS. Zakat Development: The Indonesia's Experience. Al-Infaq: Jurnal Ekonomi Islam. 2019 Jan 12;1(1).

[4] Hafidhuddin D. Islam dan Penanggulangan Kemiskinan. Al-Infaq: Jurnal Ekonomi Islam. 2018 Dec 31;3(1):25-32.

[5] al-Qaradawi Y, Wahono U, Bagio, Hafidhuddin D. Peran nilai dan moral dalam perekonomian Islam. Robbani Press; 2001.

[6] Republika. 2015. "Pakar Filantropi Didin Hafidhuddin Raih Bintang Jasa Utama." Republika.

[7] Shobron MS, Amrin IR. Islamic Education Values in the Tradition of Peta Kapanca of Mbojo Community Tribe in West Nusa Tenggara. Int. J. Adv. Sci. Technol. 2020;29(5):6802-12.

[8] Muthoifin. Shariah Hotel and Mission Religion in Surakarta Indonesia. Humanities \& Social Sciences Reviews. 2019.7(4): 973-79.

[9] Budi P. M, Readiness Towards Halal Tourism in Indonesia Perspective of Reality and Religion. Int. J. Adv. Sci. Technol. 2019;29(8):862-70.

[10] Putri P. Social Level Parameters of Banjar Society in the Tradition of Jujuran Islamic Law Perspective. InInternational Conference on Engineering, Technology and Social Science (ICONETOS 2020) 2021 Apr 22 (pp. 87-90). Atlantis Press..

[11] Nugroho MM. Outsourcing System in View of Islamic Law. InInternational Conference on Engineering, Technology and Social Science (ICONETOS 2020) 2021 Apr 22 (pp. 91-95). Atlantis Press.

[12] Hafidhuddin D. Peran strategis organisasi zakat dalam menguatkan zakat di dunia. Al-Infaq: Jurnal Ekonomi Islam. 2019 Jan 5;2(1):1-4.

[13] Varida AD. Analisis pemikiran Didin Hafidhuddin tentang zakat sektor rumah tangga modern (Doctoral dissertation, UIN Walisongo).

[14] Fattah S. M, Contribution Boarding Schools for Social Changes in Central Java Indonesia. Int. J. Psychosoc. Rehabil. 2019;24(06):7851-9.

[15] Mu'minah, Nisa"ul. 2016. Zakat Profesi Di Indonesia: Sebuah Diskusi Perbandingan Perspektif Yusuf Al-Qardhawi Dan Didin Hafidhuddin Profession.

[16] Syafa'at AK, Ekaningsih LA. Potensi zakat, infaq, shodaqoh pada badan amil zakat nasional (baznas) di kabupaten banyuwangi. INFERENSI: Jurnal Penelitian Sosial Keagamaan. 2015 Jun 1;9(1):25-46.

[17] Syafi A. Prospek Zakat dalam Perekonomian Modern. ZISWAF: Jurnal Zakat dan Wakaf. 2016 Aug 19;1(1):1-26.

[18] Muthoifin M, Firdaus I. MANAGEMENT OF PRODUCTIVE WAQF FOR EMPOWERMENT OF THE UMMAH. Profetika: Jurnal Studi Islam. 2020 Dec 29;21(2):253-9.

[19] Marwah SS, Syafe'i M, Sumarna E. Relevansi konsep pendidikan menurut Ki Hadjar Dewantara dengan pendidikan islam. TARBAWY: Indonesian Journal of Islamic Education. 2018;5(1):14-26.

[20] Qutub S, Hafidhuddin D, Mujahidin E. Metode Pembelajaran Kepemimpinan Rasulullah SAW Kepada Para Sahabat dalam Kitab Sunan Ibn Majah. Ta'dibuna: Jurnal Pendidikan Islam. 2016 Sep 8;5(1):25-59.

[21] Gunawan, I. Universitas Negeri Malang The Learning University Metode Penelitian KUALITATIF. 2016.

[22] Kohar A. GAYA KEPEMIMPINAN DAN MOTIVASI TERHADAP KINERJA PEGAWAI DI LEMBAGA AMIL ZAKAT MARHAMAH MAIMANAH. Islamic Management: Jurnal Manajemen Pendidikan Islam. 2018 Mar 15;1(01).

[23] Claramita M. Revealing" Tut Wuri Handayani"-A Student-Centred Learning Approach-by Ki Hajar Dewantara from The Early 20th Century: A Literature Review. Jurnal Pendidikan Kedokteran Indonesia: The Indonesian Journal of Medical Education. 2016;5(1):1-4. 
[24] Williams C. Research methods. Journal of Business \& Economics Research (JBER). 2007 Mar $1 ; 5(3)$.

[25] Shobron S, Muthoifin N. Education and Leadership in Indonesia: A Trilogy Concept in Islamic Perspective. Universal Journal of Educational Research.2020;8(9):4282-6

[26] Rukmana A. Analisis pendapat Didin Hafidhuddin tentang zakat produk hewani (Doctoral dissertation, UIN Walisongo).

[27] Mubarok Z, Hafidhuddin D, Tanjung H, Tamam AM. Pendidikan wirausaha bagi anak Panti Asuhan Yatim Muhammadiyah dan pengaruhnya terhadap kemandirian anak. Ta'dibuna: Jurnal Pendidikan Islam. 2018 Oct 31;7(2):152-72.

[28] Aziz A. Kepemimpinan dalam Perspektif Islam. Ilmu Ushuluddin. 2016 Jan 10;3(1):1-22.

[29] Shobron S, Anshori A. Method for Developing Soft Skills Education for Students. Universal Journal of Educational Research. 2020;8(7):3155-9.

[30] Lisnawati Y, Abdussalam A, Wibisana W. Konsep khalīfah dalam Al-QurĀn dan implikasinya terhadap tujuan Pendidikan Islam (Studi Maudu'i terhadap konsep khalīfah dalam Tafsir AlMisbah). TARBAWY: Indonesian Journal of Islamic Education. 2015;2(1):47-57.

[31] Shobron S, Ab Rahman S. Humanist islam in indonesia ahmad syafii maarif perspective. Humanities \& Social Sciences Reviews. 2019 Dec 19;7(6):780-6. 